REFLECTIONS:

NEUROLOGY AND

THE HUMANITIES

Section Editor

Anne W. McCammon,

MD, FAAN

Ludwig Gutmann, MD

Correspondence to

Dr. Gutmann:

lud-gutmann@uiowa.edu

\title{
A woman from Kenosha
}

My new patient was a charming heavyset woman whose eyelids drooped and cheeks sagged like a bed of flowers after a prolonged spring rain. Despite her expression of exhaustion and sadness, her words were full of hope and optimism.

"I've come all the way from Kenosha because I know you'll figure out the problem and fix it." I could only hope she was right.

"She could get a lot worse," Dr. Frank Forster, my attending neurologist, said the next morning on rounds. His warm, amiable smile belied the significance of the words that followed. "If she does, it will be a major effort to save her.'

It was the first time I had diagnosed a patient with myasthenia gravis. This rare illness first caught my interest a few years earlier in medical school. I had become captivated by its unique mechanism of action, its distinctive presentation, and its entirely logical treatment with an acetylcholinesterase inhibitor.

On that day, early in my career, my excitement was tempered by a sense of apprehension and concern. This was no longer a classroom discussion of an intriguing illness. What if the medication did not work as well as it was supposed to? I had never wanted to believe accounts of patients not responding or even dying. Now I worried that the pyridostigmine might not work and the patient would just get weaker and weaker. What other treatment options did I have besides a tracheostomy and an iron lung? There were none.

It was 1962, and we knew this was a disease of the neuromuscular junction. Something was damaging these junctions but, at that time, no one knew what that something was. The chemical neurotransmitter, acetylcholine, was thought to be deficient. Treating the patient with pyridostigmine to increase the amount of acetylcholine available at the injured junctions was going to be the centerpiece of our approach. I hoped it would help with her breathing as well as her other symptoms. It was the shortness of breath and the swallowing problem that were my biggest concerns. A third of patients with this disease died and that was invariably related to an inability to move enough air in and out of the lungs or not being able to keep their airways protected and open.
We did not yet know that myasthenia gravis was an autoimmune disease and that prednisone, available right there in our hospital pharmacy, had the ability to quickly send patients into remission. Those discoveries were still a decade away. They would change the outlook for patients with this disease, but not quite yet.

The patient's monotone and nasal speech were laced with confidence. "I know I'm pretty sick, but I just know you are going to make me better. I've got to make it for my sweetheart," she said, pointing to the silver-framed picture of a small girl smiling from the bathtub, her short blonde hair glistening with soap bubbles. "My only grandchild, and I have to take care of her when her mom works." The words were muddled, but their meaning was clear. I accepted them as a challenge.

At moments, I caught glimpses of the high-energy person the patient must have been before her weakness began. A woman of short stature, she only half-filled the hospital bed, as if the disease was stealing parts of her and there was only a fraction of her remaining.

The patient's 2 daughters were devoted to their mother. One visited every day. Short and plump, they both looked like their mother, except for the bright sparkle of their cheery smiles. They were just as positive about the outcome as their mother.

So began a marathon treatment schedule that evolved over the next 2 months.

"Will the new medicine...?" She stopped in midsentence.

"Pyridostigmine?" I suggested.

"Yes, will that help?" she asked.

"I hope so, but it will take some time to find the best dose for you."

I tried various combinations of dosages over the next week and finally settled on 2 tablets every 4 hours. On that regimen, the patient's swallowing was easier, her speech a little more distinct, and she tired less quickly when exercising with the physical therapist.

"It hasn't helped my shortness of breath," the patient told me one morning while suctioning the excessive saliva from her mouth. "Just a few steps with the therapists and I have to sit down. But I'm not choking on liquid as much since we've been thickening my liquids with honey." 
It was the patient's shortness of breath and the worry that she might choke that kept me awake at night. My last chore every day was to see her. Most of the time, she would say she had done a little better, but I was always unsure.

Finally, swallowing became too difficult, and the risk of aspirating liquids and food so great that the patient had to stop eating and we resorted to IV fluids. Her shortness of breath was now ever present even when she was propped up in bed. She was barely able to cough.

Oxygen was not helping and the patient was being suctioned frequently. The risk of pneumonia or worse overrode all my other concerns. This was the era before endotracheal tubes, positive pressure ventilators, and intensive care units. Instead, it meant a tracheostomy-making a small incision in the neck and placing a metal cannula into the trachea. Then we moved her bed near the nursing station where she would get constant attention. The tracheostomy made breathing and suctioning easier but the need for a Drinker respirator, the iron lung, loomed on the horizon.

I was depressed. The patient had become a friend. We were losing the battle with no hope in sight. She was bedridden, requiring repeated suctioning. Speaking around the tracheostomy tube had become almost impossible. I worried that pneumonia was imminent. One morning on rounds, I told Dr. Forster, "It's been 2 months and she's getting no better. I don't know what else to do. I think she may die."

"You may be right, but just keep plugging away," he answered. "You never know how things can change."

I was reminded of my mother's old story of 2 mice swimming in a bucket of cream. One gave up in despair and drowned. The other kept on swimming. Finally it churned the cream into butter and walked away on top. Like that mouse, I would stay positive to the end.

And then the unimaginable occurred. The patient swallowed some ice chips, her breathing was easier, and her eyelids drooped less. If she was improving, it was not due to anything we had changed in the past few days. Could it have been the tracheostomy? I didn't know.

Over the next week, the patient's strength continued to improve. She was having a spontaneous remission. And it was dramatic. Two weeks later, incredibly, she was walking with the therapists. Later that day, I plugged her tracheostomy, and she breathed without difficulty around it and coughed easily. It was time to remove it and think about going home.

"You think I'll be all right?" the patient asked. "It's a couple of hours to Kenosha." After spending months in the hospital and being close to dying, I was not surprised that she was worried.

"I think you'll be all right," I answered, "but you can always call me.”
When one of her daughters arrived that evening after work, the patient was packed and ready to go. "I haven't seen my grandbaby for so long. I am so happy."

We hugged. I was pleased for the patient and for myself. It was a major victory. Months of hard work against seemingly impossible odds and we had both prevailed. It was early evening and discharging her from the hospital was not a chore. After a quick dinner, I headed to bed, exhausted.

That night, the clamoring of the telephone brought me out of a sound sleep. It was black outside and a light rain pattered against the bedroom window. "It's my night off," I thought. "Why is anyone calling me?"

It was the daughter who had come to the hospital only occasionally. She was crying and I was suddenly overcome by a sense of doom. "It's terrible," she sobbed. "Mom and my sister were in a wreck on the way home. They were both killed."

I did not ask for details. I did not ask who would care for the baby. I said I was sorry, that I would call tomorrow. There was nothing more to say through tears, except that it was a tragedy.

I hung up the phone and slowly lay back in bed. The rain had stopped and the night was blacker than I ever remembered it. The house was silent but I guessed that sleep would be a long time coming.

None of it made sense. I had spent long hours over the last 3 months trying to save the patient while the specter of death was always nearby. And in the end, she had won the intense medical battle, only to be suddenly struck down by an ordinary traffic accident.

I felt empty, drained of all feeling. Victory had suddenly turned into defeat. All those nighttime hours spent at the patient's bedside, watching her lie there helplessly and worrying about the next crisis. It all seemed a total waste. What was the point of it all?

I remembered an observation Dr. Forster had made some time before. "In medicine, we can only win battles. Our job as physicians is to make the journey as comfortable as possible but, for each of us, the voyage has an ending."

My boyhood hero, Sherlock Holmes, said, "I play the game for the game's own sake." I knew they both were right. I would continue caring for my patients with the same energy and dedication no matter the outcome because it needed to be done-because it was the only thing to do. It was a lesson that would stay with me all my life. I drifted off to sleep.

\section{REFERENCE}

1. Doyle AC. The Adventure of the Bruce-Partington Plans. In: The Complete Sherlock Holmes. Vol II. New York: Doubleday;1922:917. 


\section{Neurology}

A woman from Kenosha

Ludwig Gutmann

Neurology 2017;88;214-215

DOI 10.1212/WNL.0000000000003476

\section{This information is current as of January 9, 2017}

\section{Updated Information \&} Services

\section{References}

Subspecialty Collections

Permissions \& Licensing

\section{Reprints}

including high resolution figures, can be found at: http://n.neurology.org/content/88/2/214.full

This article cites 1 articles, 0 of which you can access for free at: http://n.neurology.org/content/88/2/214.full\#ref-list-1

This article, along with others on similar topics, appears in the following collection(s):

Autoimmune diseases

http://n.neurology.org/cgi/collection/autoimmune_diseases Myasthenia

http://n.neurology.org/cgi/collection/myasthenia

Information about reproducing this article in parts (figures,tables) or in its entirety can be found online at:

http://www.neurology.org/about/about_the_journal\#permissions

Information about ordering reprints can be found online:

http://n.neurology.org/subscribers/advertise

Neurology ${ }^{\circledR}$ is the official journal of the American Academy of Neurology. Published continuously since 1951, it is now a weekly with 48 issues per year. Copyright @ 2017 American Academy of Neurology. All rights reserved. Print ISSN: 0028-3878. Online ISSN: 1526-632X.

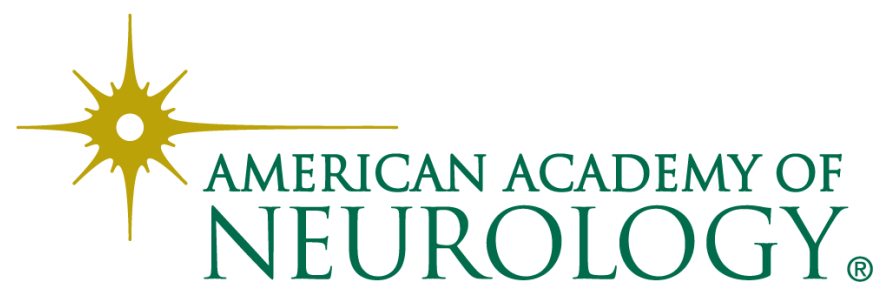

